\title{
Stanisław WÓJCIK
}

Lublin

\section{Samorząd w nauczaniu społecznym Kościoła}

Dytania czym jest i dlaczego potrzebny jest samorząd terytorialny stawiało sobie wielu wybitnych ludzi Kościoła. Z ich wypowiedzi i opinii wynika, że samorząd terytorialny jest jedną $\mathrm{z}$ podstawowych instytucji uczestnictwa obywateli $\mathrm{w}$ życiu społecznym, i - jak zauważa Andrzej Sujka - głównym obszarem ich odpowiedzialności i aktywności oraz troski o dobro wspólne. Na Soborze Watykańskim II zapisano, że dobro wspólne stanowi sumę warunków życia społecznego, jakie bądź zrzeszeniom, bądź poszczególnym członkom społeczeństwa pozwalają osiagnąć pełniej i łatwiej własną doskonałość ${ }^{1}$. Możemy więc powiedzieć, że samorząd terytorialny jest instytucją kształtującą realne obywatelstwo każdego z nas, naszą podmiotowość.

Kościół na pierwszym miejscu stawia ochronę podmiotowości każdego z nas mówiąc, że jest to podstawowy wymóg racjonalności wszelkich działan społecznych, zdrowej struktury społeczeństwa i zasad jej funkcjonowania. Możemy tu mówić o kreowaniu zasady autonomii dla małych, lokalnych społeczności. Ideę tę wyraził Jan Paweł II w encyklice Centesimus Annus pisząc: Spoleczność wyższego rzędu nie powinna ingerować w wewnętrzne sprawy spoteczności niższego rzędu, pozbawiajac je kompetencji, lecz raczej winna wspieraćja w razie konieczności i pomóc w koordynacji jej działań z działaniami innych grup społecznych dla dobra wspólnego ${ }^{2}$. Samorząd ma więc być gospodarzem na swoim terenie, ale jego autonomia może mieć tylko charakter lokalny i względny. Chodzi tu o to, aby samorząd terytorialny miał swobodę w wyrażaniu swych celów, programów i sposobów działania, by mógł dysponować własnymi środkami materialnymi i finansowymi i powoływał swe władze niezależnie i samodzielnie. Samorząd terytorialny staje się tedy jednym z wielu składników pluralizmu państwowego. Spośród mnóstwa społeczności pośrednich jest najbliższy państwu, bo jego istotnymi cechami tak jak i państwa są ludzie, terytorium i władza.

Celem samorządu terytorialnego jest kształtowanie ładu i pokoju społecznego na terenie gmin, powiatów i regionów. Ład i pokój społeczny wymagają, aby zakres kompetencji, zadań samorządów poszczególnych stopni był różny, żeby każdy z nich realizował własne dobro wspólne. Chodzi przy tym o to, żeby ich prawa i obowiązki nie wchodziły w kolizję. Kościół wskazuje, że gwarancją tego organicznego ładu społecznego, prawidłowego umiejscowienia samorządów w organizmie państwowym, jego władzy i twórczej współpracy z innymi podmiotami jest spełnianie przez nie kilku ważnych funkcji, a mianowicie stabilizacji społecznej, wychowania obywatelskiego i demokratyzacji administracji państwa.

Z praktyki demokracji parlamentarnej wiemy, że centralne władze polityczne i administracyjne często się zmieniaja. Nowe rządy dokonując tzw. restrukturalizacji wprowadzają do organów administracji państwowej przedstawicieli swojego elektoratu. Otóż samorządy terytorialne mogą równoważyć tę tendencję, gdyż ich władze wywodzą się z wyborów lokalnych,

\footnotetext{
${ }^{1}$ A. Sujka, Samorzad terytorialny. Realne obywatelstwo, Warszawa 1998, s. 13.

${ }^{2}$ Ibidem, s. 15. Por. CA, s. 48.
} 
a nie z nominacji, zwłaszcza z Komitetów Obywatelskich. Tym samym w znacznym stopniu mogą stabilizować ustrój władzy lokalnej. Nadto chronią wspólnoty lokalne przed odgórnymi, narzuconymi, często niezrozumiałymi decyzjami centralnych i terenowych władz rządowych. Stabilizują też funkcjonowanie władzy wykonawczej w terenie w zakresie stosowania i egzekwowania prawa. Tak powstaje oddolna struktura demokratycznego państwa.

Warunkiem zdrowej i pełnej demokracji (od dołu i od góry) jest całkowita wolność zrzeszania się, poszanowanie dla wspólnot naturalnych oraz możliwość uczestnictwa obywateli w różnych formach życia społecznego. Od dawna zauważono, że samorządy są szkołą obywatelskiego wychowania jednostek. Ludzie mogą uważać, że są podmiotami życia społecznego tylko wtedy, gdy psychicznie czują swoje polityczne prawa wolnościowe, a ekonomicznie cieszą się z odczuwanego pozytywnie swojego dobrego standardu materialnego, pewności życiowej, a także mogą realizować się w sferze kultury. Socjolog kultury Leon Dyczewski podkreśla, że autonomiczny samorząd stwarza ,przestrzeń”, w której każdy człowiek może uczyć się, jak trzeba realizować własne zainteresowania w dziedzinie życia społecznego, kulturalnego, gospodarczego, a także politycznego. To właśnie na poziomie samorządu gminnego jednostka może wyrabiać i rozwijać w sobie poczucie „bycia u siebie”, czy też „zakorzenienia" we własnym środowisku, a więc i współodpowiedzialności za decyzje podejmowane przez gminę na rzecz ochrony najbliższego środowiska naturalnego. Na tej drodze kształtuje się patriotyzm lokalny w sferze szeroko pojętej kultury regionalnej ${ }^{3}$. Społeczność lokalna uczy obywateli również uczestnictwa w życiu politycznym. Ludzie mogą wybierać władze gminne, powiatowe i wojewódzkie, no i sami starać się dostać do ośrodków władzy lokalnej i regionalnej. Mogą też, aktywizując się w życiu politycznym, rozwijać swoje umiejętności w zakresie władztwa administracyjnego, uczyć się sztuki kompromisu w rozwiązywaniu napotykanych problemów społecznych oraz kształtować w sobie poczucie przynależności do wspólnoty.

Społeczność lokalna z punktu widzenia katolickiej nauki społecznej winna realizować swoje, często wręcz różne, dobra wspólne, z uwagi na różnice organizacyjno-terenowe. Jednakże wśród polityków, samorządowców, prawników wciąż istnieją różnice poglądów na temat polskiego modelu terenowej organizacji administracji samorządowej. Nie ma nadal zgody co do ilości szczebli samorządowych. Wielu uważa, że powiaty są niepotrzebne, że za dużo jest małych gmin i zbyt wiele województw. Jak sądzę, powinniśmy kierować się względami ekonomicznymi, demograficznymi oraz tradycją regionów. Interesujące wypowiedzi w tych kwestiach napotkać można u teologa Józefa Majki. Jego zdaniem to co nazywamy potocznie podziałem administracyjnym, powinno mieć taki kształt, ażeby sprzyjał samodzielności regionów i powstawaniu środowisk wzajemnego współdziałania w różnych dziedzinach życia społecznego. Potrzebne są więc duże samodzielne regiony, ale potrzebne są także wspólnoty bezpośredniego kontaktu, istnieje wreszcie konieczność tworzenia ogniw pośrednich, które byłyby równocześnie rzeczywistą obecnością władzy w terenie i czynnikiem jej jednolitości. Na każdym szczeblu tego trójstopniowego podziału administracyjnego powinno się znaleźć miejsce na odpowiednie współdziałanie samorządu i administracji, z tym, że można by chyba przyjąć taką zasadę, że im niżej w teren, tym więcej samorządu i tym wyraźniejsza identyfikacja administracji z samorządem ${ }^{4}$. Jakkolwiek argumenty o znaczeniu małej gminy można uznać za słuszne z socjologicznego punktu widzenia, to wyraźnie stają one w sprzecz-

\footnotetext{
${ }^{3}$ L. Dyczewski, Kultura i społeczeństwo, „W Kręgu Kultury”, Lublin 2005, nr 2, s. 9.

${ }^{4}$ Ibidem, s. 17. Por. J. Majka, Etyka społeczna i polityczna, Warszawa 1993, s. 280-281.
} 
ności z bezwzględnymi kryteriami ekonomicznymi i demograficznymi. Trafne jest jego stanowisko w kwestii regionalności. J. Majka opowiadał się za utworzeniem 10-12 regionów geograficzno-kulturowo-ekonomicznych, „ziem”. Uważał, że byłyby one dzielnicami państwa o charakterze samorządowym. Nie miałoby to nic wspólnego z samodzielnością polityczną czy narodowościowa, bo ten problem w naszym kraju nie istnieje, ale powinno by sprzyjać rozwojowi regionalizmu kulturowego, rozwiązywaniu problematyki wzrostu ekonomicznego, rozwiązywaniu spraw ochrony środowiska, wreszcie kształtowaniu się profilu osobowości społecznej, emulacji międzyregionalnej itp. ${ }^{5}$

Samorząd w katolickiej nauce społecznej jest rozpatrywany w szerokim kontekście życia społeczno-politycznego. Jak stwierdzają przedstawiciele tej nauki (Cz. Strzeszewski, F. J. Mazurek, H. Skorowski i in.) struktura bytu społecznego wyraża się w relacji: jednostki ludzkie i niższe społeczności wbudowane w jedność nadrzędnego bytu państwowego, skierowanego całą swą rzeczywistością ku promowaniu osoby i pośrednich instytucji społecznych. Te wzajemne relacje urzeczywistniają się w postaci funkcjonowania tzw. struktur pośrednich w państwie. Można do nich zaliczyć również samorząd terytorialny, który pełni szczególną rolę w wypełnianiu przestrzeni między władzą państwową, jednostką i społecznością lokalną.

Prężna organizacja życia społecznego wymaga funkcjonowania zwłaszcza takich zasad jak: demokracja, decentralizacja władzy państwowej i pluralizm. Cz. Strzeszewski stwierdza, że domaga się ona wielostopniowej organizacji społecznej, powstawania pomiędzy jednostką a państwem szeregu społeczności pośrednich: zawodowych (korporacje), terytorialnych (samorząd terytorialny), klasowych (związki zawodowe), oświatowych (szkolnictwo prywatne), kulturalnych (stowarzyszenia kulturalne), rodzinnych. Państwo ma być w tej koncepcji naczelną organizacją społeczną koordynującą i kierującą całym organizmem społecznym, a nie tylko władzą policyjną, trzymającą w ryzach zatomizowane jednostkowo społeczeństwo ${ }^{6}$. H. Skorowski podkreśla, że państwo nie jest jedyną, lecz naczelną społecznością, która przewodzi zorganizowanym społecznościom niższego rzędu. Społeczności te powinny posiadać określony zakres samorządności. A więc w obrębie państwa powinny funkcjonować wielorakie naturalne społeczności, a także dobrowolne stowarzyszenia o charakterze politycznym, społecznym, gospodarczym, religijnym ${ }^{7}$. W świetle katolickiej nauki społecznej samorząd terytorialny jest najbardziej odpowiednim systemem umożliwiającym osiągnięcie demokracji, decentralizacji i pluralizmu. Stanowi podstawę i warunek właściwej struktury państwa demokratycznego, gdyż dla osiągnięcia istotnej i pełnej demokratyzacji życia społeczno-politycznego niezbędny jest ustrój pluralistyczny, bogactwo form organizacji społeczeństwa. Samorząd ma cechy naturalno-prawne, a więc jest odtworzeniem i utrwaleniem naturalnej ewolucji form uspołecznienia ${ }^{8}$. Funkcjonując $\mathrm{w}$ państwie posiada podmiotowość prawną, ale nie jest formą opozycji przeciwko państwu, lecz wyrazem decentralizacji demokratycznego państwa.

Należy podkreślić, że podstawowe znaczenie samorządu terytorialnego wiąże się bezpośrednio z zabezpieczeniem podmiotowości społeczeństwa. Wymienione wyżej zasady są traktowane jako fundamentalne zasady umożliwiające właściwe, tj. obywatelskie, podmioto-

\footnotetext{
${ }^{5}$ Ibidem, s. 281.

${ }^{6}$ Cz. Strzeszewski, Katolicka nauka społeczna, Lublin 1994, s. 519.

${ }^{7}$ H. Skorowski, Moralność społeczna. Wybrane zagadnienia z etyki społecznej, gospodarczej i politycznej, Warszawa 1996, s. 171.

${ }^{8}$ J. Szymczyk, Odkrywanie wartości. Z problematyki socjologiczno-aksjologicznej, Lublin 2004, s. 217. Por. Cz. Strzeszewski, Katolicka..., op. cit., s. 520.
} 
we funkcjonowanie społeczności. W sposób naturalny domaga się ona wielostopniowej organizacji, tj. istnienia szeregu społeczności pośrednich między jednostką a państwem. Jedną z tego rodzaju społeczności jest społeczność terytorialna, która w katolickiej nauce społecznej uznana jest za najlepszą gwarancję zabezpieczenia wolności i podmiotowości jednostki wobec niebezpieczeństwa totalnej omnipotencji państwa. Cz. Strzeszewski zauważa, że samorząd jest wyrazem rezygnacji ze strony państwa z części swych uprawnień na rzecz niższych społeczności. Władza najwyższa pozostając w rękach państwa może jednak przybrać różne formy mniej lub więcej scentralizowane. Im większa centralizacja, tym większa omnipotencja władzy, niebezpieczeństwo nadużyć społecznych ${ }^{9}$.

W myśl katolickiej nauki społecznej, samorząd terytorialny ma trzy zasadnicze cechy: łączy ogół mieszkańców danego terytorium, co nadaje mu charakter powszechności, jego celem jest dobro wspólne ludności zamieszkałej na jego terytorium, co przydaje mu cechę wszechstronności oraz posiada władzę, która również może domagać się posłuszeństwa.

Podstawową wartością samorządu jest wspólnota osób żyjąca dla dobra wspólnego i dla dobra osób jednocześnie. Dlatego na gruncie nauki społecznej Kościoła samorząd określa się bądź jako szczególny związek osób stale zamieszkałych na określonym obszarze (ujęcie podmiotowe), bądź prawnie wyodrębnioną jednostkę podziału terytorialnego z zamieszkałą na niej ludnością (ujęcie przedmiotowe). Samorząd terytorialny reprezentuje interesy społeczności lokalnych i posiada ustawowo określony stopień autonomii, będąc integralną częścią państwa $^{10}$.

Nauka społeczna Kościoła uznaje, że prawidłowe funkcjonowanie społeczności państwowej domaga się oparcia całego życia społecznego na określonych zasadach. Zasady te definiuje się jako ogólne twierdzenia dotyczące istnienia i funkcjonowania społeczeństwa w państwie. Doniosłe znaczenie ma zasada pomocniczości. Papież Pius XI sformułował tę zasadę następująco: Nienaruszalnym i niezmiennym pozostaje owo najwyższe prawo filozofii społecznej: co jednostka z własnej inicjatywy i własnymi siłami może zdziałać, tego nie wolno jej wydzierać na rzecz społeczeństwa, podobnie niesprawiedliwościa, szkoda społeczna $i$ zaktóceniem ustroju jest zabieranie mniejszym i niższym społecznościom tych zadań, które moga spetnić i przekazywanie ich społecznościom większym i wyższym. Każda akcja społeczna ze swego celu i ze swej natury ma charakter pomocniczy: winna pomagać członkom organizmu społecznego, nie niszczyć ich lub wchłaniac ${ }^{11}$. Wywodzi się ona z założenia, że osoba ludzka jest podmiotem wszelkich spraw. Inne instytucje powinny być tworzone jako pomocnicze w stosunku do jego działań. Zasada ta przede wszystkim odnosi się do państwa. Ma ono stworzyć autonomię i wspierać organizacje społeczne, służyć obywatelowi. Pomocniczość wymaga podziału kompetencji, władzy i środków materialnych pomiędzy państwem a zorganizowanym społeczeństwem. Wymaga to decentralizacji w niektórych dziedzinach społeczno-gospodarczo-administracyjnych. W toku tego procesu wyłania się personalistyczny ustrój państwa oparty na dualizmie administracyjnym, na ograniczonej autonomii władzy ${ }^{12}$.

Zasada pomocniczości jest wielowymiarowa. Jako zasada ontologiczna wskazuje, że dobro wspólne jest dla osoby, która jest bytem względnie absolutnym, bo jednocześnie człowiek

\footnotetext{
${ }^{9}$ Cz. Strzeszewski, Katolicka..., op. cit., s. 519.

${ }^{10}$ H. Skorowski, Moralność..., op. cit., s. 174.

11 A. Sujka, Samorzad..., op. cit., s. 14. Por. QA, n. 79.

12 J. Majka, Chrześcijańska myśl społeczna. Filozofia społeczna, Warszawa 1982, s. 165; S. Wójcik, Dynamika i bariery w rozwoju społeczności lokalnych i samorzadu terytorialnego w Polsce, „Przegląd Politologiczny” 2002, nr 1, s. 114-115.
} 
jako jednostka jest dla społeczności. Tak więc osoba ludzka i jej dobro jest podstawowym celem społeczności. Jak stwierdza Cz. Strzeszewski z faktu, że osoba ludzka jest ostatecznym podmiotem i celem życia społecznego wynika, że zaspokojenie potrzeb ludzkich wyznacza charakter społeczności i zakres jej uspołecznienia. Jeżeli mniejsza społeczność może zaspokoić potrzeby człowieka, to nie ma podstawy naturalnej do powstawania społeczności szerszej ${ }^{13}$.

Pomocniczość ma również wymiar prawny. Jest ona w relacji do praw społecznych. Stąd każda społeczność mniejsza nie musi odwoływać się do społeczności większych, jeśli nie ma konieczności, a każda społeczność wyższa musi szanować prawo podmiotowe społeczności niższych ${ }^{14}$.

Zasada pomocniczości jest także zasadą moralną, to znaczy, że wiąże człowieka i społeczność w sumieniu co do przestrzegania obowiązków. Możemy zatem powiedzieć, że zasada pomocniczości ma na celu wspieranie procesu tworzenia wielostopniowych struktur społeczności, w których będzie poszanowanie człowieka jako osoby i wspólnot osobowych. A więc można ją uznać za zasadę o charakterze personalistycznym, gdyż jej treścią jest wskazanie konieczności, a jednocześnie granic wolności człowieka i mniejszych społeczności. Wskazuje, iż podstawą i uzasadnieniem wolności jest osobowy wymiar istoty ludzkiej ${ }^{15}$.

Inną ważną zasadą organizacji życia społecznego jest solidarność. To związek między podmiotami władzy i działanie dla wspólnego dobra. Solidarność obejmuje wszystkie podmioty od osoby, przez struktury pośrednie, po państwo. Dla skutecznego jej funkcjonowania potrzebna jest obecność państwa w takich obszarach rzeczywistości polityczno-społecznej, jak np. w spełnianiu funkcji redystrybucji dochodu narodowego, właściwej lokalizacji inwestycji służących wyrównywaniu poziomu życia pomiędzy regionami, czy jako gwaranta rzetelnego rozdziału dotacji i subwencji.

W katolickiej nauce społecznej źródłowym punktem odniesienia dla zrozumienia funkcjonowania tych zasad w społeczeństwie jest personalizm społeczny. Uznaje on zasadę wrodzonej godności osoby ludzkiej, to znaczy, że osobę ludzką należy szanować, afirmować dla niej samej, bo jest osobą. Społeczeństwo istnieje dla niej i dzięki niej. A więc człowiek jako osoba w życiu społecznym ma pierwszeństwo i autonomię. Osoba jest bowiem ostatecznym i podstawowym podmiotem społeczności. Funkcjonowanie społeczeństwa jest najlepsze w realizacji personalistycznej koncepcji człowieka, czyli społeczeństwa przez osobę i dla osoby. Godność osoby ludzkiej domaga się budowy życia społecznego w oparciu o zasady dobra wspólnego, pomocniczości, solidarności i sprawiedliwości. Zasady te porządkują dany system społeczny na miarę człowieka jako osoby, gdyż umożliwiają stworzenie takich struktur, w których osoba ma zapewnione poszanowanie swej godności i posiada szansę pełnego, integralnego rozwoju. Katolicka nauka społeczna widzi zatem najgłębsze podstawy samorządu w płaszczyźnie antropologiczno-personalistycznej.

Personalizm społeczny uznać należy za fundament i uzasadnienie funkcjonowania samorządu terytorialnego, gdyż personalizm jako koncepcja życia społecznego definiuje i zabezpiecza żeby osoba była centralną wartością i mogła mieć swoją godność, możliwość rozwoju, zakres wolności i była traktowana sprawiedliwie.

W dokumentach społecznych Kościoła podkreśla się, że koncepcja człowieka jako osoby ma podstawowe znaczenie dla życia społecznego. Błędna, niepełna antropologia osoby skut-

\footnotetext{
${ }^{13}$ Cz. Strzeszewski, Katolicka..., op. cit., s. 517.

${ }^{14}$ H. Skorowski, Moralność..., op. cit., s. 176.

${ }^{15}$ Cz. Strzeszewski, Katolicka..., op. cit., s. 520.
} 
kuje również błędną koncepcją życia społecznego. Dlatego katolicy odrzucają zarówno marksistowską, jak i liberalną koncepcję człowieka i społeczeństwa. Marksizm zakładał, że poprzez zniesienie własności prywatnej uda się osiągnąć stan komunizmu, w którym zbędne będzie państwo. W liberalizmie własność prywatna jest podstawą, ale i tu państwo musi zamierać lub jedynie zachowuje funkcję dozoru prawnego ochraniania bogatych.

Państwo według katolicyzmu jest formą substancjalną społeczności, a władza państwa jest duszą społeczności, określa ją. Katolicy nie wyobrażają sobie społeczeństwa bez państwa. Państwo określa podstawowe zasady wszelkich dziedzin życia. W tej koncepcji najgłębiej jest uzasadniona konieczność upodmiotowienia zarówno jednostek, jak i grup społecznych. Przy tym też ma charakter socjalny, tzn. wspiera grupy i kategorie społeczne, które nie są w stanie iść o własnych siłach. Państwo chroni więc w praktyce wrodzoną godność każdej osoby i tym samym buduje sprawiedliwy ustrój personalistyczny. Jest to konsekwencją miłości i solidarności międzyludzkiej. Tylko takie państwo buduje personalistyczny, solidarny i sprawiedliwy ład społeczny. Personalizm społeczny nie jest indywidualizmem, lecz syntezą indywidualizmu z societyzmem. Bo osoba nie istnieje bez drugiej osoby. Osoba jako absolutna, izolowana jednostka nie ma sensu. Samorząd terytorialny wpisujący się w tę filozofię jest państwu i społeczeństwu autentycznie potrzebny.

Na koniec rozważmy kwestię zagrożeń i odpowiedzialność katolików za rozwój wspólnot lokalnych. Skoro samorząd wygląda tak dobrze na tle katolickiej nauki społecznej, to dlaczego rzeczywistość tak bardzo odbiega od tego obrazu? Sądzę, że w tym okresie przejściowym, w którym żyjemy, jest to efekt dominującego i żywiołowego liberalizmu, ścierającego się z ustępującym systemem myślenia postkomunistycznego. Podzielam zdanie Cz. S. Bartnika, że liberalizm jako kierunek ogólny ma pewne wartości dla społeczeństw zachodnich jednak duszących się w obecnej technologii, w strukturach już ustabilizowanych, chociaż dzisiaj i tam rośnie bezrobocie, rozwarstwienie społeczne, przestępczość, rozkład moralny. Ale w krajach postkomunistycznych, gdzie podkopane zostały podstawowe struktury jak religia, etyka, tradycja, prawo, poczucie godności, liberalizm pogłębia ten chaos radykalnie. Bywa on tu pojmowany jako wolność bezkarnego grabienia, gnębienia innych. Przeciwstawiony religii jest zarazem przeciwny wyższym wartościom i podstawowym prawom społecznym. Skutkuje kompletnym chaosem i ogromną bezczelnością wszelkich zachowań ${ }^{16}$.

W odniesieniu do samorządu można powiedzieć, że liberalizm jakby przenosił się z wyższych pięter budowli globalistycznej do niższych, zagrażając również życiu samorządowemu. Zdaniem Bartnika w teorii samorządy winny sprzyjać wolności obywatelskiej. W Polsce XIX i połowy XX wieku były nawet namiastką naszej suwerenności. Wychodziły względnie dobrze właśnie w kontekście mocnych struktur religijnych i etycznych, jakimi były dla Anglików - anglikanizm, dla Niemców - protestantyzm, dla Rosji - prawosławie. Dla Polaków katolicyzm stanowił niekwestionowany miernik wolności i prawa. Niestety ta podpora katolicka upadła w życiu publicznym po roku 1944. Państwo komunistyczne złamało wręcz ten kanon godności i uczciwości katolickiej Polaka. Co gorsza, po 1989 roku nadal czynią to samo postkomuniści, masoni, lobby filosemickie oraz „katolicy prywatni”. Dlatego nawet na terenie katolickiej Polski rozwinęła się społeczna i moralna dżungla, walka o władzę i pieniądze, duch egoistyczny. W tej sytuacji również samorządy cierpią na wyraźny brak odpowiednich ludzi, warunków kulturowych i skutecznego prawodawstwa. Dla samorządowych stanowisk i rad nie ma jednego spoiwa, pojęcie dobra wspólnego jest w naszych czasach niezrozumiałe, za-

${ }^{16}$ Cz. S. Bartnik, O godność polska wobec UE, „Nasz Dziennik”, nr 171, 24 VII 2002, s. 11. 
leżność od aferzystów i ignorantów społecznych zbyt duża ${ }^{17}$. Kilkakrotnie już pisałem, że W sferze samorządowej powinien panować dialog i współpraca, ale zbyt często chodzi o własne partykularne cele, zyski, urządzenie się w życiu. Ze względu na skalę całego społeczeństwa, jak i regionalną pragnę zwrócić uwagę na rozwijający się personalizm społeczny, który wzywa katolików do odpowiedzialności za rozwój wspólnot lokalnych. W katolickiej nauce społecznej wzywa się wiernych związanych z różnymi partiami politycznymi, ruchami i stowarzyszeniami katolickimi, aby aktywnie przystąpili do pracy w samorządach. Potrzeby są ogromne - pisze A. Sujka - Kościół oczekuje i wymaga, aby wierni, którzy zechcą podjąć to wyzwanie, znali i umieli stosować katolicką naukę społeczną, aby byli wyposażeni w solidną wiedzę samorządową i fachową. Wielu z nich takimi umiejętnościami dysponuje. Bo przecież od lat angażowali się na rzecz rodzin i młodzieży, pracy oświatowej, przygotowania liderów różnych wspólnot, rozwoju kultury życia codziennego, ochrony środowiska naturalnego i praw człowieka. Kościół ze swoją nauką społeczną jest ekspertem w sprawach ludzkich i świeccy mogą wydatnie przyczynić się do odnowy moralnej społeczności, w których żyją. W tej dziedzinie jest wiele do zrobienia i to na dwóch płaszczyznach: poprzez udział we władzach samorządowych lub podejmując współpracę z nowymi samorządami ${ }^{18}$.

Przykładowo, w odniesieniu do stanowisk liderów samorządowych można by założyć, że wójt, burmistrz i prezydent reprezentujący katolicki punkt widzenia starałby się harmonizować swe prawa i obowiązki z dobrem państwa i wspólnoty w ramach prawa i etyki. Personalistyczny model władzy oparty jest na regulacji prawnej, na wolnych wyborach bez manipulacji, respektuje interesy społeczności i wypełnia prawa społeczne i administracyjne. Kieruje się etyką niezależnie od układów politycznych ze względu na godność osoby. Może to jest ta właściwa droga, aby Kościół wkraczając w różne dziedziny nauki swoje osiagnięcia i etykę wniósł do konkretnych sfer działań, żebyśmy nie byli skazani na kadłubowe poglądy liberałów i socjaldemokratów.

\section{Summary}

This paper contributes to the deliberations of a doctrinal and comparative nature. It indicates one of the sources providing for the dynamics of the evolution of self-government, the need to promote a new philosophy of self-government, and particularly emphasizes the significance of social personalism. Presentation of this issue allows better comprehension of various aspects of the ideological situation of self-government authorities and local communities.

\footnotetext{
${ }^{17}$ Ibidem, s. 11.

18 A. Sujka, Samorzqd..., op. cit., s. 23-24.
} 
